\title{
Antimicrobial Potentials of Vernonia amygdalina and Honey on Vancomycin-Resistant Staphylococcus aureus from Clinical and Environmental Sources
}

\author{
Jacob Olaoluwa Oluyege ${ }^{1}$, Paul Ikechukwu Orjiakor1 ${ }^{*}$, Busayo Mutiat Olowe², \\ Ukhureigbe Oluchi Miriam ${ }^{3}$, Oguntoye David Oluwasegun ${ }^{1}$ \\ ${ }^{1}$ Department of Microbiology, Faculty of Science, Ekiti State University, Ado-Ekiti, Nigeria \\ ${ }^{2}$ Department of Science Laboratory Technology, Ekiti State University, Ado-Ekiti, Nigeria \\ ${ }^{3}$ Department of Microbiology, Federal University, Oye-Ekiti, Nigeria \\ Email: *paul.orjiakor@eksu.edu.ng
}

How to cite this paper: Oluyege, J.O., Orjiakor, P.I., Olowe, B.M., Miriam, U.O. and Oluwasegun, O.D. (2019) Antimicrobial Potentials of Vernonia amygdalina and Honey on Vancomycin-Resistant Staphylococcus aureus from Clinical and Environmental Sources. Open Access Library Journal, 6: e5437.

https://doi.org/10.4236/oalib.1105437

Received: May 5, 2019

Accepted: May 28, 2019

Published: May 31, 2019

Copyright () 2019 by author(s) and Open Access Library Inc.

This work is licensed under the Creative Commons Attribution International License (CC BY 4.0).

http://creativecommons.org/licenses/by/4.0/

\begin{abstract}
Background and Objective: Vancomycin has been a cost effective and frontline antibiotic in the treatment of methicillin resistant Staphylococcus aureus for many years. However, some vancomycin-resistant Staphylococcus aureus (VRSA) have been recently reported. This study therefore aimed to determine the antimicrobial effects of Vernonia amygdalina and honey on VRSA from environmental and clinical sources. Materials and Methods: Vernonia amygdalina plant was sourced from farmland within Ekiti State University vicinity while honey samples, Blessed honey and Sunshine honey, were purchased from stores in Ado-Ekiti and Ondo State respectively. Ethanolic and aqueous extracts of $V$. amygdalina parts were prepared using standard method. The extracts were screened for the presence of some secondary metabolites using standard procedures. Honey brands were also analyzed physicochemically for these parameters: appearance, colour, $\mathrm{pH}$ and moisture content, according to standard methods. The antimicrobial activities of extracts of $V$. amygdalina and different samples of honey against the VRSA were performed using the Kirby Bauer's method. Data from the study were statistically analyzed using descriptive, Pearson's correlation and regression. Results: Phytochemical screening of $V$. amygdalina extracts revealed the presence of alkaloids, flavonoids, tannins, saponins and phenols at varied concentrations. Comparatively, the ethanolic extracts of the plant parts had higher concentration of these metabolites than their aqueous extracts. Differences were observed in the physicochemical parameters of both honey samples. Also, the
\end{abstract}


antimicrobial activities of the plant extracts and honey brands demonstrated effective inhibition against most of the VRSA, though, in a concentration dependent manner. Conclusion: Findings from this study suggest that the leaves, barks and roots of this plant as well as honey could be very useful in the therapy against VRSA.

\section{Subject Areas}

Microbiology

\section{Keywords}

Vancomycin-Resistant $S$. aureus, Honey, Vernonia amygdalina, Antibacterial Activity

\section{Introduction}

Antimicrobial resistance acquisition in microorganisms has become a common microbiology research theme in the last few decades, particularly with respect to $S$. aureus. A significant evolution has been the acquisition of methicillin resistance in $S$. aureus, which still remained a major problem globally. With the increase in prevalence of methicilin-resistant $S$. aureus (MRSA), vancomycin became the drug of choice for treatment of MRSA infections [1]. For several years, there was no evidence of vancomycin resistant development in $S$. aureus. However, the isolation of strains with different degrees of vancomycin resistance has emerged in clinical methicilin-resistant $S$. aureus strains, generating significant concern in both the clinical and research community [2]. In addition to this, fully vancomycin-resistant $S$. aureus (VRSA) with van $A$ gene has emerged. Although, more breakthroughs have been made in respect of discovering new drugs against MSRA and VRSA, there are still reports on MRSA/VRSA infections in clinical and environmental samples [3]. In recent times, attention has been shifted to the exploitation of natural products of plants and animals, which have been reported to demonstrate a wide range of antimicrobial activities against human pathogens [4] [5] [6].

Vernonia amygdalina, commonly known as bitter leaf (English), oriwo (Edo), ewuro (Yoruba), shikawa (Hausa), and olubu (Igbo), is a tropical shrub, 1 - $3 \mathrm{~m}$ in height with petiole leaf of about $6 \mathrm{~mm}$ in diameter, and elliptic in shape [7]. The leaves are dark green coloured with a characteristic odour and a bitter taste. The species is indigenous to tropical Africa and is found wild or cultivated all over sub-Saharan Africa [8]. All parts of the plant are pharmacologically useful. Both the roots and leaves are used in phytomedicine to treat fever, hiccups, kidney disease and stomach discomfort, among others [9] [10]. Antihelmitic and antimalarial properties [11] as well as antitumourigenic properties [4], have also been reported for extracts from the plant. Other studies have demonstrated hypoglycaemic and hypolipidaemic effects of the leaf extract in experimental ani- 
mals [5] [12]. The aqueous and ethanolic extracts of this plant were known to have great antimicrobial effect against different microorganisms responsible for various human infections [13]. The extracts displayed potent antimicrobial activity against organisms such as Staphylococcus aureus, Escherichia coli, Klebsiella pneumonia, Bacillus subtilis, Pseudomonas aeruginosa, Candida albicans and Aspergillus niger [13].

Honey is a traditional topical treatment for infected wound and can be effective on antibiotic resistance strains of bacteria [6]. The pure honey contains alkaloids, anthraquinone glycosides, cardiac glycosides, flavonoids and reducing compounds. The antibacterial properties of honey includes, the release of hydrogen peroxide, some honey have an additional phytochemical antibacterial compound. The antibacterial property of honey is also due to osmotic effect of its high sugar content as it has an osmolarity sufficient to inhibit the microbial growth [6]. It is reported that proliferation of peripheral blood B-Lymphocytes and T-Lymphocytes in cell culture is stimulated by honey at concentration as low as $0.1 \%$. In addition, the glucose content of honey and the acid $\mathrm{pH}$ (between $\mathrm{pH} 3$ - $\mathrm{pH} 4$ ) may assist in bacteria destroying action of monophages [6].

Considering the rising trend in antibiotic resistant pathogens in recent times, it is therefore, pertinent to investigate the potentials of known medicinal plants on antibiotic-resistant isolates so as to source for complementary or alternative chemotherapeutic agents. This study was carried out to determine the antibacterial properties of $V$. amygdalina leaf extract and honey against vancomycin-resistant staphylococcus.

\section{Materials and Methods}

\subsection{Study Area and Duration of Study}

Study took place in Ekiti State University, Ado-Ekiti, the capital city of Ekiti State, Nigeria between April and August, 2013.

\subsection{Source of Test Microorganisms}

Vancomycin-resistant Staphylococcus aureus (VRSA) isolates from clinical and environmental samples from Ekiti State University Teaching Hospital, Nigeria in a previous study (unpublished) were used in this study.

\subsection{Collection of Vernonia amygdalina Plants and Honey}

Vernonia amygdalina plants (bitter leaf) were sourced from farmland within the vicinity of Ekiti State University. Commercial honey which included "blessed honey" and "sunshine honey" purchased from stores in Ado-Ekiti and Ondo State respectively were used in the study. All the materials were taken to the microbiology laboratory of Ekiti State University for analyses.

\subsection{Preparation of Extracts of Vernonia amygdalina}

This was carried out using the standard method employed by Malairajan et al. 
[14]. The various parts of Vernonia amygdalina (leaves, stem back and roots) were collected, air-dried and ground to powder with pestle and mortar. Twenty gram (20 g) of each ground plant material was separately extracted with $200 \mathrm{ml}$ of $70 \%$ ethanol and $200 \mathrm{ml}$ of distilled water (via maceration) in a separate container over 24 hours period in a sterile conical flask plugged with sterile non-absorbent cotton wool wrapped in aluminum foil. These were subjected to filtration and the resulting filtrates evaporated to dryness using a rotary evaporator at $40^{\circ} \mathrm{C}$. Each residue of the plant extract was then used to prepare solutions of different concentrations for antimicrobial susceptibility testing.

\subsection{Phytochemical Screening of Extracts of Vernonia amygdalina}

Phytochemical screening of both ethanolic and aqueous extract of $V$. amygdalina were performed according to standard procedures of Evans [15] and Sofowora [16]. The extracts were screened for the presence of secondary metabolites which included alkaloids, flavonoids, saponins, tannins, anthraquinones, phlobatannins and phenolics.

\subsection{Determination of Antimicrobial Activity of Vernonia amygdalina}

The antimicrobial activities of different concentrations of ethanolic and aqueous extracts of $V$. amygdalina against the vancomycin resistant $S$. aureus (VRSA) was performed using the standard procedures of CLSI [17]. Test materials were prepared by diluting each extract of $V$. amygdalina in sterile distilled water at different dilutions (concentration): $10 \mathrm{mg} / \mathrm{ml}, 20 \mathrm{mg} / \mathrm{ml}, 30 \mathrm{mg} / \mathrm{ml}$ and 40 $\mathrm{mg} / \mathrm{ml}$. Muller Hington Agar plates were prepared and the test organisms were transferred to already solidified agar plates from the standardized inoculum with the use of sterile swab sticks. Wells were prepared using sterile cork borer and filled with test materials. The inoculated petri-dishes were incubated at $37^{\circ} \mathrm{C}$ for $24 \mathrm{hrs}$ and observed for zone of inhibition.

\subsection{Physicochemical Analysis of Honey}

The honey samples were investigated for the following physicochemical parameters: appearance, colour, $\mathrm{pH}$ and moisture content using standard procedures of Farida et al. [18]. The $\mathrm{pH}$ of the honey samples was determined using the $\mathrm{pH}$ meter (Hanan M-22054). Ten gram of the honey sample was dissolved in $75 \mathrm{ml}$ of distilled water in $250 \mathrm{ml}$ beaker. The solution was stirred and the $\mathrm{pH}$ electrode was immersed in the solution and the $\mathrm{pH}$ was recorded. Moisture content in honey was measured by means of refractometer. One to two drops of honey sample was pipetted onto the main prism of a honey refractometer (Atago 8436, Japan). The light was led in from the window of the refractometer and a clear boundary line between the light and dark fields was observed through the eyepiece by adjusting the focusing ring. The moisture content was read directly from the scale where the boundary line falls. The value was corrected by adding 
the indicated plus or minus percentage point of the thermometer on the instrument itself.

\subsection{Determination of the Antimicrobial Activity of Honey}

The antimicrobial activities of different concentrations of the honey samples against the vancomycin-resistant $S$. aureus (VRSA) were performed using the Kirby Bauer's method (CLSI, 2013). Test materials were prepared by diluting each honey sample in distilled water at different dilutions (concentration): $20 \%$, $40 \%, 60 \%, 80 \%$ and neat honey i.e., 100\%. Mueller Hinton Agar plates were prepared and the test organisms transferred to already solidified agar plates from the standardized inoculum with the use of sterile swab sticks. Wells were prepared on the agar plates using sterile cork borer. The wells were filled with test materials, and the plates were incubated at $37^{\circ} \mathrm{C}$ for 24 hours. Zones of inhibition were observed and measured.

\subsection{Statistical Analysis}

The data generated from the phytochemical screening were analyzed using descriptive statistics and regression. Also the mean zone of inhibition of the plant parts from both ethanolic and aqueous extracts were anlysed using descriptive statistics while the relationship between the potency of both extract was investigated using Pearson's correlation and multiple regression. The significant level was set to 0.05 .

\section{Results}

\subsection{Colour Characteristics of Extracts of V. amygdalina}

Different colour characteristics of aqueous and ethanolic extracts of the parts of $V$. amygdalina were observed. Aqueous extract appeared yellow, while ethanolic extract was green (Table 1).

\subsection{Qualitative and Quantitative Phytochemical Screening of Different Parts of $V$. amygdalina}

The qualitative phytochemical screening showed the presence and absence of some secondary metabolites in both the ethanolic and aqueous extracts of the parts of the plant (Table 2). While the quantitative phytochemical screening of the different parts of the plant showed varied concentration of these secondary metabolites (Table 3). The table revealed that ethanolic extract of these parts had higher quantity when compared with that of aqueous extract. And it was also observed that alkaloids, tannins, and phenols were present in high concentration, flavonoids in moderate concentration while saponins were present in low concentration in both ethanolic and aqueous extracts. However, alkaloids were not detected in the aqueous extract of the plant root, flavonoids were also not detected in both ethanolic and aqueous extract of the plant root (Table 3). The statistical analysis on the concentration of phytochemicals present in ethanolic 
Table 1. Colour characteristics of extracts of $V$. amygdalina.

\begin{tabular}{ccc}
\hline Plant parts & Aqueous extract & Ethanolic extract \\
\hline Leaves & Yellow & Light Green \\
Stem back & Yellow & Green \\
Roots & Light yellow & Green \\
\hline
\end{tabular}

Table 2. Qualitative phytochemical screening of different parts of $V$. amygdalina.

\begin{tabular}{cccccccc}
\hline & \multicolumn{7}{c}{ Part of $V$. amygdalina assayed } \\
\cline { 2 - 7 } Plant constituent & & Leaf & \multicolumn{7}{c}{ Stem Bark } & \multicolumn{2}{c}{ Root } \\
\cline { 2 - 7 } & EE & AE & EE & AE & EE & AE \\
\hline Alkaloids & + & + & + & + & + & - \\
Anthraquinones & - & - & - & - & - & - \\
Flavonoids & + & & + & + & + & - & - \\
Tannins & + & + & + & + & + & + \\
Saponins & + & + & + & + & + & + \\
Phlobatannins & - & - & - & - & - & - \\
Phenols & + & & + & + & + & + & +
\end{tabular}

Key: $\mathrm{EE}=$ ethanol extract, $\mathrm{AE}=$ aqueous extract, $+=$ present, and $-=$ absent.

Table 3. Quantitative phytochemical screening of different parts of $V$. amygdalina.

\begin{tabular}{ccccccccc}
\hline & \multicolumn{3}{c}{ Ethanolic Extract } & \multicolumn{5}{c}{ Aqueous Extract } \\
\cline { 2 - 8 } & Leaf & $\begin{array}{c}\text { Stem } \\
\text { back }\end{array}$ & Root & $\begin{array}{c}\text { Mean value } \\
\pm \text { S.D }\end{array}$ & Leaf & $\begin{array}{c}\text { Stem } \\
\text { back }\end{array}$ & Root & $\begin{array}{c}\text { Mean value } \\
\pm \text { S.D }\end{array}$ \\
\hline $\begin{array}{c}\text { Alkaloids } \\
\text { (mg/g) }\end{array}$ & 74.9 & 68.5 & 17.7 & $53.7 \pm 31.3$ & 25.0 & 23.6 & ND & $16.2 \pm 14.1$ \\
$\begin{array}{c}\text { Flavonoids } \\
\text { (mg/g) }\end{array}$ & 21.5 & 20.6 & ND & $14.0 \pm 12.2$ & 18.0 & 12.9 & ND & $10.3 \pm 9.3$ \\
$\begin{array}{c}\text { Tannins } \\
\text { (mg/g) }\end{array}$ & 54.0 & 51.7 & 21.6 & $42.4 \pm 18.1$ & 32.5 & 29.3 & 10.9 & $24.2 \pm 11.7$ \\
$\begin{array}{c}\text { Saponins (\%) } \\
\text { Phenols }\end{array}$ & 14.2 & 11.2 & 4.7 & $10.0 \pm 4.9$ & 10.4 & 7.4 & 2.2 & $6.7 \pm 4.2$ \\
(mg/g) & 82.4 & 75.8 & 38.2 & $65.5 \pm 23.8$ & 53.6 & 51.3 & 17.5 & $40.8 \pm 20.2$ \\
\hline
\end{tabular}

$\mathrm{r}=0.858014 ; \mathrm{P}$-value $=0.06$. Key: $\mathrm{EE}=$ ethanol extract, $\mathrm{AE}=$ aqueous extract, $\mathrm{ND}=$ not detected.

and aqueous extracts revealed that there is a positive, strong but no significant relationship between the concentration of phytochemicals in these extracts $(r=$ 0.858 ; -value $=0.06$ )

\subsection{Antimicrobial Activities of V. amygdalina on Hospital and Environmental Isolates}

From Table 4 and Table 5, all the test organisms showed similar responses to the different concentration of both ethanolic and aqueous extract of $V$. amygdalina. 
Table 4. Susceptibility pattern of vancomycin-resistant $S$. aureus from hospital samples to the mean concentration (mg/ml) of ethanolic and aqueous extract of $V$. amydalina.

\begin{tabular}{|c|c|c|c|c|c|c|c|c|c|c|}
\hline \multirow{2}{*}{ Test Organisms } & \multicolumn{5}{|c|}{$\begin{array}{l}\text { Different Concentration }(\mathrm{mg} / \mathrm{ml}) \text { of Ethanolic } \\
\text { Extract of } V \text {. amydalina }\end{array}$} & \multicolumn{5}{|c|}{$\begin{array}{c}\text { Different Concentration }(\mathrm{mg} / \mathrm{ml}) \text { of Aqueous } \\
\text { Extract of } V \text {. amydalina }\end{array}$} \\
\hline & Control & 10 & 20 & 30 & 40 & Control & 10 & 20 & 30 & 40 \\
\hline BH154 & 0 & 10 & 12 & 17 & 18 & 0 & 0 & 0 & 8 & 16 \\
\hline BH157 & 0 & 0 & 0 & 6 & 14 & 0 & 0 & 0 & 0 & 7 \\
\hline PH178 & 0 & 4 & 8 & 15 & 19 & 0 & 6 & 10 & 12 & 17 \\
\hline HH181 & 0 & 0 & 0 & 8 & 17 & 0 & 0 & 0 & 3 & 14 \\
\hline HH206 & 0 & 3 & 7 & 12 & 15 & 0 & 3 & 7 & 11 & 13 \\
\hline BH210 & 0 & 0 & 4 & 8 & 13 & 0 & 0 & 0 & 8 & 14 \\
\hline ZH226 & 0 & 4 & 12 & 16 & 18 & 0 & 0 & 3 & 7 & 15 \\
\hline ZH229 & 0 & 0 & 4 & 10 & 15 & 0 & 0 & 0 & 6 & 11 \\
\hline $\mathrm{BH} 241$ & 0 & 3 & 9 & 14 & 18 & 0 & 0 & 0 & 2 & 11 \\
\hline $\mathrm{BH} 245$ & 0 & 11 & 13 & 17 & 19 & 0 & 0 & 9 & 15 & 16 \\
\hline BH247 & 0 & 0 & 0 & 3 & 13 & 0 & 0 & 0 & 0 & 4 \\
\hline SH262 & 0 & 7 & 12 & 14 & 16 & 0 & 3 & 7 & 11 & 15 \\
\hline BH268 & 0 & 0 & 4 & 12 & 15 & 0 & 0 & 0 & 4 & 9 \\
\hline BH273 & 0 & 12 & 15 & 16 & 18 & 0 & 12 & 16 & 17 & 19 \\
\hline BH280 & 0 & 3 & 7 & 11 & 15 & 0 & 0 & 2 & 10 & 13 \\
\hline TH296 & 0 & 0 & 3 & 11 & 17 & 0 & 0 & 0 & 6 & 14 \\
\hline
\end{tabular}

$r=0.713$; p-value $=0.002$. Key: $\mathrm{H}-$ isolate from beddings (hospital); $\mathrm{PH}-$ isolate from phone (hospital); $\mathrm{HH}-$ isolate from hand (hospital); $\mathrm{ZH}-\mathrm{isolate}$ from zinc (hospital); $\mathrm{SH}-$ isolate from sample bottle (hospital); $\mathrm{TH}-$ isolate from thermometer (hospital).

Table 5. Susceptibility pattern of vancomycin-resistant $S$. aureus from environmental samples to the mean concentration (mg/ml) of ethanolic and aqueous extract of $V$. amydalina.

\begin{tabular}{|c|c|c|c|c|c|c|c|c|c|c|}
\hline \multirow{2}{*}{ Test Organisms } & \multicolumn{5}{|c|}{ Different Concentration $(\mathrm{mg} / \mathrm{ml})$ of Ethanolic } & \multicolumn{5}{|c|}{$\begin{array}{l}\text { Different Concentration }(\mathrm{mg} / \mathrm{ml}) \text { of Aqueous } \\
\text { Extract of } V \text {. amydalina }\end{array}$} \\
\hline & Control & 10 & 20 & 30 & 40 & Control & 10 & 20 & 30 & 40 \\
\hline AE11 & 0 & 0 & 0 & 11 & 13 & 0 & 0 & 0 & 2 & 8 \\
\hline SE17 & 0 & 0 & 7 & 13 & 15 & 0 & 0 & 0 & 6 & 12 \\
\hline SE35 & 0 & 0 & 3 & 13 & 17 & 0 & 0 & 0 & 12 & 15 \\
\hline FE46 & 0 & 0 & 0 & 6 & 13 & 0 & 0 & 0 & 4 & 15 \\
\hline BE60 & 0 & 0 & 0 & 9 & 16 & 0 & 0 & 3 & 11 & 14 \\
\hline BE71 & 0 & 4 & 12 & 14 & 16 & 0 & 0 & 0 & 7 & 10 \\
\hline SE76 & 0 & 0 & 0 & 8 & 15 & 0 & 0 & 0 & 2 & 6 \\
\hline DFE87 & 0 & 0 & 0 & 3 & 11 & 0 & 0 & 0 & 0 & 7 \\
\hline PE95 & 0 & 0 & 0 & 9 & 14 & 0 & 0 & 0 & 6 & 14 \\
\hline WE101 & 0 & 3 & 7 & 11 & 16 & 0 & 0 & 6 & 9 & 13 \\
\hline WE104 & 0 & 0 & 4 & 5 & 12 & 0 & 0 & 0 & 8 & 12 \\
\hline BE112 & 0 & 0 & 3 & 13 & 15 & 0 & 0 & 6 & 7 & 10 \\
\hline SE146 & 0 & 0 & 4 & 14 & 18 & 0 & 0 & 3 & 11 & 13 \\
\hline
\end{tabular}

$r=0.381522$; p-value $=0.198331$. Key: AE_isolate from air (environmental); SE_-isolate from soil (environmental); FE_isolate from animal feed (environmental); BE-isolate from beddings (environmental); DFE-isolate from dried fish (environmental); PE-isolate from phone (environmental); WE-isolate from water (environmental). 
It was observed that the degree of potency of the plant extracts increased with increased concentration, that is, as the concentration of the extracts of the plant increased, the test organisms became more susceptible. Statistical analysis showed that there is a positive, strong and significant relationship between the potency of the concentration of ethanolic and aqueous extract on hospital isolates $(r=0.7132$; $\mathrm{p}$-value $<0.05)$. However, there was a positive, weak and no significant relationship between the potency of the concentration of ethanolic and aqueous extract of the plant on environmental samples as $r$ value $=0.381$ and $\mathrm{p}$-value $>0.05$.

\subsection{Physicochemical Characteristics and Antimicrobial Activities of Blessed and Sunshine Honey Samples}

The physicochemical characteristics of blessed and sunshine honey samples are shown in Table 6. Differences were observed in appearance, colour, $\mathrm{pH}$ and moisture content of the honey samples. The antimicrobial activities of different concentrations of the two honey samples on the vancomycin resistant $S$. aureus from hospital and environmental sources are shown in Table 7 and Table 8 respectively. The degree of potency of both honey samples increased with increased concentration. Although Blessed honey sample appeared to be more potent at every concentration while Sunshine honey was only potent at concentrations above $40 \%$ and $60 \%$ against hospital and environmental sources respectively (Table 7 and Table 8). Statistically, there was a weak but no significant relationship between the potency of the two honey samples at different concentration on both hospital isolates $(r=0.237$; $\mathrm{p}$-value $=0.378)$ and environmental isolates $(\mathrm{r}=0.142$; $\mathrm{p}$-value $=0.645)$.

\section{Discussion}

This study was conducted to determine the antimicrobial potential of extracts of $V$. amygdalina and honey. The plant extracts demonstrated significant antibacterial activities against the VSRA. Generally, differences in antimicrobial properties of a plant extract may be attributed to the age of the plant used, freshness of plant materials, physical factors (temperature, light, water), contamination by field microbes, adulteration and substitution of plants, incorrect preparation and dosage [19] [20] [21]. It was found out that the higher the concentration of the extract, the higher the diameter of zones of the inhibition. The observation made on the bioactivity of the plant extracts correlate with the report of Evbuomwan [22] who also reported that $V$. amygdalina has potential bioactive phytochemicals which are responsible for its antimicrobial activity against multidrug resistant bacterial isolates.

The phytochemical screening revealed the presence of various concentrations of secondary metabolites in the extracts. Quantitative phytochemical screening revealed that alkaloids, tannins, and phenols were present in high concentration, flavonoids in moderate concentration while saponins were present in low concentration. Anthraquinones and phlobatannins are not detected in any of the 
Table 6. Physico-chemical characteristics of honey samples.

\begin{tabular}{ccc}
\hline Parameters & Blessed Honey & Sunshine Honey \\
\hline Appearance & $\begin{array}{c}\text { Visible presence of pollen and } \\
\text { crystallized honey } \\
\text { Light golden amber }\end{array}$ & Clear \\
Colour & 3.6 & Dark brown \\
pH & 17.8 & 3.9 \\
Moisture Content (\%) & & 19.8 \\
\hline
\end{tabular}

Table 7. Susceptibility pattern of selected VRSA from hospital samples to different concentration (\%) of blessed and sunshine honey.

\begin{tabular}{|c|c|c|c|c|c|c|c|c|c|c|}
\hline \multirow{2}{*}{ Hospital Isolates } & \multicolumn{5}{|c|}{$\begin{array}{l}\text { Blessed honey } \\
\text { (conc. in \%) }\end{array}$} & \multicolumn{5}{|c|}{$\begin{array}{l}\text { Sunshine honey } \\
\text { (conc. in \%) }\end{array}$} \\
\hline & 20 & 40 & 60 & 80 & 100 & 20 & 40 & 60 & 80 & 100 \\
\hline BH154 & 10 & 15 & 17 & 17 & 20 & 0 & 0 & 0 & 0 & 21 \\
\hline BH157 & 0 & 0 & 0 & 0 & 16 & 0 & 0 & 0 & 8 & 13 \\
\hline PH178 & 0 & 9 & 15 & 18 & 24 & 0 & 0 & 8 & 9 & 15 \\
\hline HH181 & 0 & 0 & 0 & 0 & 21 & 0 & 0 & 0 & 0 & 0 \\
\hline HH206 & 0 & 0 & 16 & 16 & 21 & 0 & 0 & 0 & 0 & 0 \\
\hline BH 210 & 0 & 0 & 0 & 14 & 23 & 0 & 0 & 0 & 0 & 13 \\
\hline ZH226 & 0 & 10 & 10 & 15 & 20 & 0 & 0 & 0 & 12 & 19 \\
\hline ZH229 & 0 & 0 & 12 & 14 & 22 & 0 & 0 & 0 & 0 & 0 \\
\hline BH241 & 0 & 0 & 8 & 9 & 19 & 0 & 0 & 0 & 0 & 0 \\
\hline BH245 & 13 & 13 & 15 & 21 & 23 & 0 & 0 & 8 & 8 & 17 \\
\hline BH247 & 0 & 0 & 0 & 12 & 21 & 0 & 0 & 0 & 0 & 15 \\
\hline SH262 & 0 & 13 & 13 & 19 & 26 & 0 & 0 & 0 & 15 & 15 \\
\hline BH268 & 11 & 14 & 14 & 15 & 20 & 0 & 0 & 0 & 0 & 0 \\
\hline BH273 & 8 & 13 & 17 & 17 & 24 & 0 & 0 & 0 & 0 & 22 \\
\hline BH 280 & 0 & 11 & 15 & 16 & 23 & 0 & 0 & 0 & 0 & 0 \\
\hline TH296 & 0 & 0 & 0 & 8 & 20 & 0 & 0 & 0 & 0 & 0 \\
\hline
\end{tabular}

$R=0.236523 ; p$-value $=0.3778$. Key: $\mathrm{BH}-$ isolate from beddings (hospital); $\mathrm{PH}-$ isolate from phone (hospital); $\mathrm{HH}-$ isolate from hand (hospital); $\mathrm{ZH}-$ isolate from zinc (hospital); $\mathrm{SH}-$ isolate from sample bottle (hospital); $\mathrm{TH}-$ isolate from thermometer (hospital).

plant extract. Phytochemical screening helps to reveal the chemical nature of constituents of the plant extract and the one that predominates over the others. It may also be used to search for bioactive agents that could be used in the synthesis of useful drugs [23].

The honey brands used in this study were effective against most of the vancomycin resistant $S$. aureus isolates, although at different concentrations. This corroborates earlier reports on antibacterial activity of honeys from other countries [24] [25]. The low pH or acidity of honey is believed to have important contribution to its antibacterial activity. Indeed, previous studies claimed that 
Table 8. Susceptibility pattern of selected VRSA from environmental samples to different concentration (\%) of blessed and sunshine honey.

\begin{tabular}{|c|c|c|c|c|c|c|c|c|c|c|}
\hline \multirow{2}{*}{$\begin{array}{l}\text { Environmental } \\
\text { isolates }\end{array}$} & \multicolumn{5}{|c|}{$\begin{array}{l}\text { Blessed honey } \\
\text { (conc. in \%) }\end{array}$} & \multicolumn{5}{|c|}{$\begin{array}{l}\text { Sunshine honey } \\
\text { (conc. in \%) }\end{array}$} \\
\hline & 20 & 40 & 60 & 80 & 100 & 20 & 40 & 60 & 80 & 100 \\
\hline AE11 & 0 & 0 & 0 & 0 & 21 & 0 & 0 & 0 & 0 & 0 \\
\hline SE17 & 11 & 11 & 12 & 14 & 15 & 0 & 0 & 0 & 9 & 15 \\
\hline SE35 & 0 & 0 & 0 & 0 & 20 & 0 & 0 & 0 & 14 & 20 \\
\hline FE46 & 0 & 0 & 0 & 8 & 22 & 0 & 0 & 0 & 0 & 12 \\
\hline BE60 & 0 & 0 & 0 & 0 & 17 & 0 & 0 & 0 & 0 & 0 \\
\hline BE71 & 14 & 15 & 18 & 18 & 23 & 0 & 0 & 0 & 8 & 10 \\
\hline SE76 & 0 & 0 & 12 & 13 & 19 & 0 & 0 & 0 & 0 & 20 \\
\hline DFE87 & 0 & 0 & 0 & 17 & 21 & 0 & 0 & 0 & 0 & 0 \\
\hline PE95 & 0 & 0 & 0 & 15 & 25 & 0 & 0 & 0 & 12 & 22 \\
\hline WE101 & 0 & 0 & 0 & 0 & 20 & 0 & 0 & 0 & 10 & 15 \\
\hline WE104 & 0 & 0 & 8 & 10 & 25 & 0 & 0 & 0 & 0 & 14 \\
\hline BE112 & 0 & 0 & 0 & 15 & 18 & 0 & 0 & 0 & 11 & 17 \\
\hline SE146 & 0 & 0 & 10 & 14 & 23 & 0 & 0 & 0 & 0 & 15 \\
\hline
\end{tabular}

$\mathrm{r}=0.141615 ; \mathrm{p}$-value $=0.644448 . \mathrm{Key}$ : AE-isolate from air (environmental); $\mathrm{SE}-$ isolate from soil (environmental); FE-isolate from animal feed (environmental); BE-isolate from beddings (environmental); DFE-isolate from dried fish (environmental); PE-isolate from phone (environmental); WE-isolate from water (environmental).

the antibacterial activity of honey is credited to its acidity along with osmolarity and other factors [25] [26]. Moreover, other physicochemical parameters, in particular the coloration of honey due to the presence of any particular chemical constituent(s) contributed to its antimicrobial activity as reported by Taormina et al. [24]. The differences in the observed antibacterial activities of the two samples of honey could be attributed to several reasons. One possibility might be related to the differences in susceptibility of each species of microorganism to the antibacterial activity of honey used. Similar observations were reported by some researchers [24] [27] [28]. Another possibility could be due to the different floral sources utilized by the bees and the geographical factors like temperature, humidity where the honey was produced [24]. Other possible reason could also be the differences in putative antibacterial agent(s) present in these honeys. These agents may utilize hydrogen peroxide and non-peroxide antioxidant components [25].

\section{Conclusion}

This study has shown that the extracts of $V$. amydalina and honey samples were effective in eliminating VRSA, although the concentrations may vary for different samples. It is worthy of note that the constituents in the extracts of the 
leaves, barks and roots of $V$. amydalina as well as honey could be very useful in chemotherapy.

\section{Significant Statement}

This study discovered the antimicrobial potential of extracts $V$. amydalina and honey against VRSA. Therefore, the extracts of $V$. amydalina and honey can be beneficial for chemotherapeutic purpose. This study will help researchers to uncover the potentials in $V$. amydalina and honey in combating infection with VRSA. Thus, further research can be carried out on the active ingredients, purification of these active ingredients and their toxicological studies before they can be formulated into dosage forms for use against potential disease causing microbes.

\section{Conflicts of Interest}

The authors declare no conflicts of interest regarding the publication of this paper.

\section{References}

[1] Balet, A.M., Garau, J., Gould, I.M., Lia, C.H. and Mazzei, T. (2013) Vancomycin in the Treatment of Meticillin-Resistant $S$. aureus (MRSA) Infection, End of an Era? Journal of Global Antibiotic Research, 1, 23-30. https://doi.org/10.1016/j.jgar.2013.01.002

[2] Cui, L., Neoh, H.M., Shoji, M. and Hiramatsu, K. (2009) Contribution of vraSR and graSR Point Mutations to Vancomycin Resistance in Vancomycin-Intermediate $S$. aureus. Antimicrobial Agents Chemotherapy, 53, 1231-1234. https://doi.org/10.1128/AAC.01173-08

[3] McGuinness, W.A., Malachowa, N. and DeLeo, F.R. (2017) Vancomycin Resistance in Staphylococcus aureus. Yale Journal of Biology and Medicine, 90, 269-281.

[4] Izevbigie, E.B., Bryant, J.L. and Walker, A. (2004) A Novel Natural Inhibitor of Extracellular Signal Related Kinases and Human Breast Cancer Cell Growth. Experimental Biology of Medicine, 229, 163-169. https://doi.org/10.1177/153537020422900205

[5] Nwanjo, H.U. (2005) Efficacy of Aqueous Leaf Extract of Vernonia amygdalina on the Plasma Lipoprotein and Oxidative Status of Diabetic Rat Models. Nigerian Journal of Physiological Sciences, 20, 39-42.

[6] Rakhi, K.C., Dogade, N.G. and Meghna, K. (2010) Antimicrobial Activity of Indian Honey against Clinical Isolates. Asiatic Journal of Biotechnology Resources, 1, 35-38.

[7] Igile, G.O., Oleszyek, W., Burda, S. and Jurzysta, N. (1995) Nutritional Assessment of Vernonia amygdalina Leaves in Growing Mice. Journal of Agricultural Food Chemistry, 43, 2126-2166. https://doi.org/10.1021/jf00056a038

[8] Bosch, C.H., Borus, D.J. and Siemonsma, J.S. (2005) Vegetables of Tropical Africa. Conclusions and Recommendations Based on PROTA 2: "Vegetables". PROTA Foundation, Wageningen, Vol. 10, 68.

[9] Gill, L.S. (1992) Ethnomedical Uses of Plants in Nigeria. Uniben Press, Benin City, 243. 
[10] Hamowia, A.M. and Saffaf, A.M. (1994) Pharmacological Studies on Vernonia amygdalina (Del) and Tithonia diversifolia (Gray). Veterinary Medicine Giza, 2, 91-97.

[11] Abosi, A.O. and Raseroka, B.H. (2003) In Vivo Antimalarial Activity of Vernonia amygdalina. British Journal of Biomedical Science, 60, 89-91. https://doi.org/10.1080/09674845.2003.11783680

[12] Akah, P.A. and Okafor, C.I. (1992) Hypoglycemic Effect of Vernonia amygdalina in Experimental Rabbits. Plant Medical Research, 1, 6-10. https://doi.org/10.1002/ptr.2650060318

[13] Arekemase, M.O., Oyeyiola, G.P. and Balogun, K.I. (2013) Assessment of Bitter Leaf (Vernonia amygdalina) on Some Selected Pathogenic Microorganisms from University of Ilorin Teaching Hospital. Journal of Microbiology, Biotechnology and Food Sciences, 2, 2360-2365.

[14] Malairjan, P., Gopalakrish, G., Narasimhan, K. and Veni, K.J.K. (2008) Evaluation of Antiulcer Activity of Polyathialongitolia (Sonn) the Waites in Experimental Animals. Indian Journal of Pharmacology, 40, 126-128.

https://doi.org/10.4103/0253-7613.42306

[15] Evans, W.C. (2002) Trease and Evans Pharmacognosy. 15th Edition, W.B Saunders, Edinburgh, 585.

[16] Sofowora, A. (2005) Medicinal Plants and Traditional Medicine in Africa. Spectrum Books, Ibadan, 289.

[17] Clinical and Laboratory Standards Institute (CLSI) (2013) Performance Standards for Antimicrobial Susceptibility Testing; Twenty-First Informational Supplements. M100 S21, 31:1. Clinical and Laboratory Standards Institute, Wayne.

[18] Farida, I., Rashid, M., Noor, I., Ghulam, S., Asif, M. and Hammad, S. (2014) Physicochemical Analysis of Honey Samples Collected from Local Markets of Rawalpindi and Islamabad, Pakistan. American Journal of Biochemistry, 4, 35-40.

[19] Calixto, J.B. (2000) Efficacy, Safety, Quality Control, Marketing and Regulatory Guidelines for Herbal Medicines (Phytotherapeutic Agents). Brazil Journal of Medical Biological Research, 33, 19-189. https://doi.org/10.1590/S0100-879X2000000200004

[20] Okigbo, R.N. and Omodamiro, O.D. (2006) Antimicrobial Effects of Leaf Extracts of Pigeon Pea on Some Human Pathogens. Journal of Herbs Spices of Medicinal Plant, 12, 117-127. https://doi.org/10.1300/J044v12n01_11

[21] Okigbo, R.N. and Igwe, D.I. (2007) The Antimicrobial Effects of Piper guineense "Uziza" and Phyllantus amarus "Ebe-Benizo" on Candida albicans and Streptococcus faecali. s. Acta Microbiologicaet Immunologica Hungarica, 54, 353-366. https://doi.org/10.1556/AMicr.54.2007.4.3

[22] Evbuomwan, L., Chukwuka, E.P., Obazemi, E.I. and Ilevbare, L. (2018) Antibacterial Activities of Vernonia amygdalina Leaf Extracts against Multidrug Resistant Bacterial Isolates. Journal of Applied Science and Environmental Management, 22, 17-21. https://doi.org/10.4314/jasem.v22i1.4

[23] Okoli, R.L., Turay, A.A., Mensah, J.K. and Aigbe, A.O. (2009) Phytochemical and Antimicrobial Properties of Four Herbs from Edo State, Nigeria. Report and Opinion, 1, 67-73.

[24] Taormina, P.J., Niemira, B.A. and Bauchart, L.R. (2001) Inhibitory Activity of Honey against Foodborne Pathogens as Influenced by the Presence of Hydrogen Peroxide and Level of Antioxidant Power. International Journal of Food Microbiology, 69, 217-225. https://doi.org/10.1016/S0168-1605(01)00505-0 
[25] Melissa, A.M., Olga, I.P.Z. and Randy, W.W. (2004) Growth Inhibition of Food Borne Pathogens and Food Spoilage Organisms by Select Raw Honeys. International Journal of Food Microbiology, 97, 1-8. https://doi.org/10.1016/j.ijfoodmicro.2004.03.025

[26] Molan, P.C. (1992) The Antibacterial Activity of Honey: The Nature of the Antibacterial Activity. Bee World, 73, 5-28. https://doi.org/10.1080/0005772X.1992.11099109

[27] Nzeako, B.C. and Hamdi, J. (2000) Antimicrobial Potential of Honey on Some Microbial Isolates. Medical Sciences, 2, 75-79.

[28] Ceyhan, N. and Ugur, A. (2001) Investigation of in Vitro Antimicrobial Activity of Honey. Rivista di Biologia, 94, 363-371. 